ppi $201502 Z U 4645$

Esta publicación cientifica en formato digital es continuidad de la revista impresa ISSN-Versión Impresa 0798-1406 / ISSN-Versión on line 2542-3185Depósito legal pp

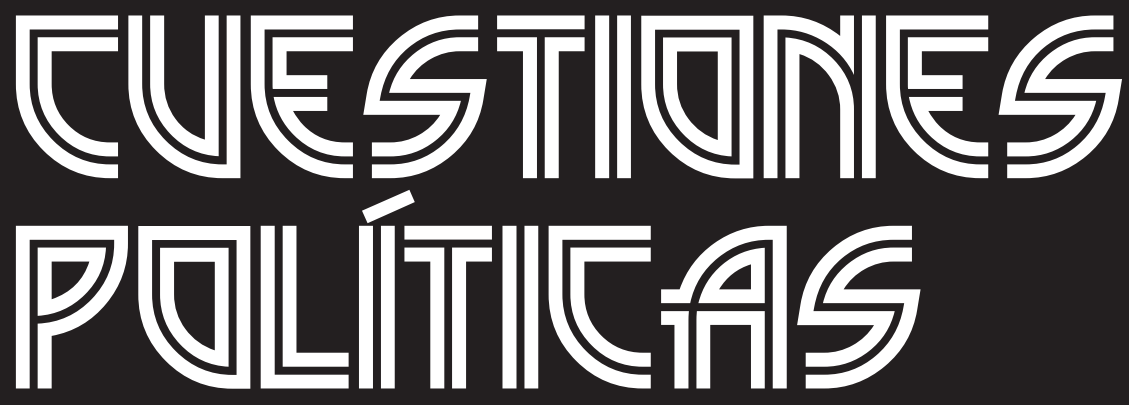

Instituto de Estudios Políticos y Derecho Público "Dr. Humberto J. La Roche' de la Facultad de Ciencias Jurídicas y Políticas de la Universidad del Zulia Maracaibo, Venezuela
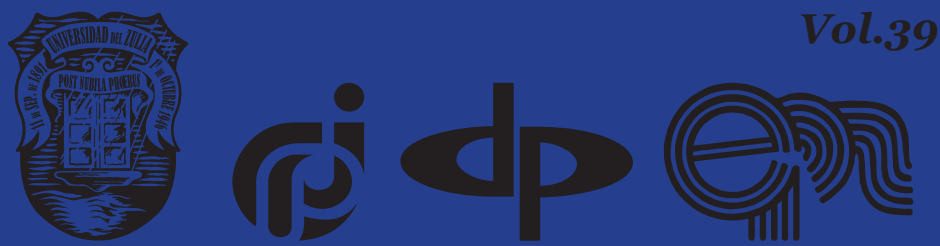


\title{
Model of social protection for war veterans to improve their social well-being and health in the Russian Federation
}

\author{
DOI: https://doi.org/10.46398/cuestpol.3968.08
}

\author{
Elena G. Pankova* \\ Dinara A. Bistyaykina ** \\ Tatiana V. Solovieva *** \\ Alena A. Antipova **** \\ Olga M. Lizina $* * * *$
}

\begin{abstract}
The relevance of the studied problem is determined by the need to constantly improve the system of social protection of veterans in changing socio-cultural conditions to make it more consistent with the tasks and priorities of social and demographic policy and modern social threats and risks. The objective of the article is to study the Russian experience of social protection of war veterans and to develop practical recommendations for its improvement by updating the model of social protection of veterans to improve their social well-being and health. Research methods: systemic (integrative) method, assuming the need to analyze social, economic, legal, and other measures to support veterans and the elderly; expert survey; modelling. As a result of the study, the authors draw conclusions and offer recommendations on the improvement and implementation of the model of social protection of war veterans to improve their social well-being and health. The practical significance of the conducted study lies in the possibility of using the developed recommendations in the sphere of social policy and social work with veterans and the elderly, social gerontology, and practical activities of social protection institutions for senior citizens.
\end{abstract}

Keywords: social protection for veterans; social welfare; social health; social support measures; Russian federation.

\footnotetext{
* National Research Mordovian State University named after N.P. Ogarev, Saransk, Russia. ORCID ID: https://orcid.org/oooo-0oo1-6080-4877.Email: print84@mail.ru

** National Research Mordovian State University named after N.P. Ogarev, Saransk, Russia. ORCID ID: https://orcid.org/oooo-ooo1-9959-1995. Email: dinaraas@mail.ru

*** National Research Mordovian State University named after N.P. Ogarev, Saransk, Russia. ORCID ID: https://orcid.org/oooo-0002-2899-7514. Email: tanysha_v@bk.ru

**** National Research Mordovian State University named after N.P. Ogarev, Saransk, Russia. ORCID ID: https://orcid.org/oooo-ooo2-3341-4133. Email: aljona.ntpv@mail.ru

****** National Research Mordovian State University named after N.P. Ogarev, Saransk, Russia. ORCID ID: https://orcid.org/oooo-ooo1-7965-4151. Email: lizinaom@yandex.ru
} 
Elena G. Pankova, Dinara A. Bistyaykina, Tatiana V. Solovieva, Alena A. Antipova y Olga M. Lizina

Model of social protection for war veterans to improve their social well-being and health in the

\section{Modelo de protección social para veteranos de guerra para mejorar su bienestar y salud en la Federación de Rusia}

\section{Resumen}

La relevancia del problema estudiado está determinada por la necesidad de mejorar constantemente el sistema de protección social de los veteranos en condiciones socioculturales cambiantes, para hacerlo más consistente con las tareas y prioridades de la política social y demográfica y las amenazas y riesgos sociales modernos. El objetivo del artículo es estudiar la experiencia rusa de protección social de veteranos de guerra y, al mismo tiempo, desarrollar recomendaciones prácticas para su mejora mediante la actualización del modelo de protección social de veteranos para optimizar su bienestar social y salud. Se hizo uso del método sistémico (integrador), asumiendo la necesidad de analizar medidas sociales, económicas, legales y de otro tipo para apoyar a los veteranos y ancianos; encuesta de expertos; modelado. Como resultado del estudio, los autores extraen conclusiones y ofrecen recomendaciones sobre la mejora e implementación del modelo de protección social de los veteranos de guerra para mejorar su bienestar social y salud. La trascendencia práctica del estudio realizado radica en la posibilidad de utilizar las recomendaciones desarrolladas en el ámbito de la política social y el trabajo social con veteranos y ancianos, gerontología social y actividades prácticas de instituciones de protección social para personas mayores.

Palabras clave: protección social para veteranos; bienestar social; salud social; medidas de apoyo social; federación rusa.

\section{Introduction}

Veterans are one of the categories of citizens who have traditionally become the object of social protection in the Russian Federation. Firstly, their specific position in society is determined by their special socio-legal status and significant services to the country. It acts as an expression of guarantees to create conditions that ensure a decent life, honor, and respect in society. Secondly, war veterans represent a special sociodemographic group that has certain social, economic, psychological, and other characteristics. It may also be noted here that veterans mostly belong to the senior categories of the population. For them, the issues of preserving health, prolonging active/working age, reducing morbidity and mortality, effective and accessible social rehabilitation, and adaptation, and increasing life expectancy, which have become a priority in Russia's demographic policy at the present stage, are extremely relevant. 
Thirdly, veterans are a heterogeneous social group. Several categories of veterans are defined by law. The classification is based on the criteria of special merits in defending the homeland, military, or other public services, as well as significant work contribution (conscientious and longlasting work). There are also special features inherent in certain categories of veterans. Thus, under Article 1 of Federal Law №5-FL of January 12, 1995 "On Veterans", the following categories of veterans are distinguished: veterans of the Great Patriotic War, combat veterans (who served in the USSR, Russia, or other states), military service veterans, and veterans of labour.

According to Article 3 of the Federal Law of 12 January 1995 № 5-FL "On Veterans", combat veterans are defined as: 1) servicemen; 2) former servicemen dismissed from the reserve or retired; 3) people called up for military service; 4) persons in the rank of regular and superior staff of internal affairs bodies and state security bodies; 5) employees of internal affairs bodies and state security bodies; 6) employees of the Ministry of Defense of the USSR and the Ministry of Defense of the Russian Federation; 7) employees of institutions and bodies of the penal system; 8) other civilians.

As of August 2020, the following categories of veterans are registered in Russia as recipients of social protection (support): former minor prisoners of concentration camps, ghettos, and interned persons (77,578 persons); veterans of the Great Patriotic War, their widows and family members (440,462 persons); veterans of military service (224,737 persons); labour veterans and members of their families (11,271,626 persons); veterans, participants in hostilities, and members of their families $(1,621,340$ persons); disabled veterans of the Great Patriotic War, disabled veterans of hostilities, persons with equivalent status, and members of their families (272,456 persons); persons awarded the title of "Resident of the Siege of Leningrad" and their family members (99,260 persons); persons who worked in the rear during the Great Patriotic War, participants in the labour front, and members of their families (469,143 persons).

In the Republic of Mordovia, as of 2020, there are 241 veterans and disabled veterans of the Great Patriotic War, 1,726 veteran widows, and 7,633 persons considered equivalent to veterans of the Great Patriotic War - prisoners of Nazi concentration camps, workers of the rear, residents of besieged Leningrad, and others.

The system of social protection for veterans is a set of measures aimed at providing guaranteed living conditions, maintaining their livelihood, and providing social support to ensure a decent standard of living, active work, honor, and respect in society for this category of citizens. The Federal Law of 12 January 1995 № 5-FL "On Veterans" reflects the most important legal provisions regulating the guaranteed social protection of veterans in the 
Elena G. Pankova, Dinara A. Bistyaykina, Tatiana V. Solovieva, Alena A. Antipova y Olga M. Lizina

Model of social protection for war veterans to improve their social well-being and health in the Russian Federation

Russian Federation. The federal law also defines a system of social support measures for this category of citizens, which includes provision of housing; pension provision; right to receive a single cash payment and a range of social services; the right to supplementary monthly benefits; medical and prosthetic/orthopedic assistance; the possibility of using social benefits; the right to receive annual payments.

In our view, the state of social health and well-being of the studied social group is an integrative characteristic of the effectiveness of the social protection system for any category of the population. Thus, the heterogeneity of the category of war veterans according to socio-demographic, cultural, psychological, and other characteristics, and the complexity of the existing system of social protection of this category determine the relevance of the study of social well-being and health of war veterans, as it allows us to identify the areas of social tension.

\section{Literature Review}

The problem of quality of life and social well-being of elderly people and veterans is topical, debated, and, by its nature, interdisciplinary. The object of study is various measures and directions of social policy towards veterans (Obradovic, 2017; Perkins et al., 2020; Ben-Shalom et al., 2016; Bolotova, 2016). Particular attention is paid to veterans' income levels, social and economic practices, the extent to which their life potential is in demand, and the political and cultural processes taking place in society, which are identified as determinants of social well-being.

Social well-being is considered as an integral indicator of adaptation (Krupets, 2003) and as an indicator of the quality of life of older people (Xavier and Ferraz, 2003; Burnell et al., 2017; Swed et al., 2020; Googe, 2020).

In the works of researchers from different countries, we can observe some differences in the interpretation and choice of indicators of social well-being. The terms "subjective well-being" and "perception of the quality of life" used in American socio-psychological and economic research are synonymous to this concept. The structure of the concept includes subjective experiences and states, the nature of social interactions, and psychological well-being (depression, suicide, etc.) (Chen et al., 2020; Utsumieva et al., 2015; Kobozeva et al., 2007; Dushatsky, 2004). The following constructs are called components of social well-being: people's feelings of satisfaction with their health, financial situation, social status, legal security, family's livability, interpersonal relations. These components indicate the state of the political, environmental, socio-economic, and interethnic situation (Londadzhim, 2011; O’Reilly and Dolan, 2017). 
The objects of study are the impact of mutual support on the social wellbeing and issues of social integration and segregation of veterans (Drebing et al., 2018).

Thus, the literature substantiates a set of different socio-economic, demographic, psychological, legal, and other indicators of veterans' social well-being and emphasizes their connection with the level of social security. This determines the necessity to study the types of social services and support measures that make up the social protection system, ensuring a high level and quality of life for those who have special merits to the state and society.

\section{Materials and Methods}

Based on the Department of Social Work of N.P. Ogarev Mordovia State University, a study, and a series of activities under the regional grant № 18-411-130001 with the financial support of the Russian Foundation of Basic Research (RFBR) and the Government of the Republic of Mordovia on "Transformation of social well-being of war veterans in conditions of Russian reforms at the regional level" were carried out. In 2018-2019, a cycle of empirical studies was conducted.

1. Pilot study "Social well-being of war veterans (combat veterans)" (November 2018-March 2019). The main objective was to identify the social well-being and health indicators of war veterans (combat veterans). War veterans (combat veterans) between the ages of 55 and 65 were interviewed. The research was carried out based on the State Budgetary Institution of the Republic of Mordovia "Saransk Complex Centre of Social Services", the AllRussian Public Organization of Veterans "Battle Brotherhood", the Council of the Mordovian Regional Branch of the All-Russian Public Organization of Veterans (Pensioners) of War and Labour of the Armed Forces and Law Enforcement Agencies ( $n=48$ people). The type of sampling was targeted.

2. Pilot study "Social support for the elderly in the Republic of Mordovia" (February-December 2018). The objective of the study was to justify the relevance of social and economic support measures and the specifics of interdepartmental interaction in solving the problems of social health of war veterans (combat veterans) in the Republic of Mordovia. The veterans aged 55-65 and over 65 were interviewed. The research was carried out based on the Saransk Complex Centre of Social Services, the All-Russian Public Organization of Veterans "Battle Brotherhood", and the Council of the Mordovian Regional Branch of the All-Russian Public Organization of Veterans (Pensioners) of War and Labour of the Armed Forces and Law Enforcement Agencies ( $\mathrm{n}=86$ people). The type of sampling was targeted. 
Elena G. Pankova, Dinara A. Bistyaykina, Tatiana V. Solovieva, Alena A. Antipova y Olga M. Lizina

Model of social protection for war veterans to improve their social well-being and health in the Russian Federation

3. Pilot study "Social health and support measures for war veterans (combat veterans)" (February-December 2019). The objective of the study was to identify the degree of satisfaction of war veterans (combat veterans) with social assistance and support measures in the Republic of Mordovia. The respondents of this study were veterans living in the Republic of Mordovia, aged 55-84, who were registered in the departments of social support under the jurisdiction of the Ministry of Social Protection, Labour, and Employment of the Republic of Mordovia $(n=50$ people). The type of sampling was targeted.

4. Pilot study "Comparative analysis of social well-being of the elderly and war veterans (combat veterans)" (October-November 2019). The main objective was a comparative analysis of objective and subjective factors affecting the social well-being of the elderly and war veterans (combat veterans) in Saransk. A questionnaire was administered to the recipients of social services of the Saransk Complex Centre of Social Services aged 60-74 years $(n=150$ people). The type of sampling was targeted.

5. Pilot study "Social health of war veterans (combat veterans) as a goal of the functioning of social institutions" (October-November 2019). The objectives of the study were to substantiate the needs of war veterans (combat veterans) in the context of transformational processes of modern society affecting their social health and to highlight the prospects and recommendations for solving the problem of maintaining the social health of war veterans (combat veterans) through interdepartmental interaction of social institutions. Experts were interviewed from the staff of the Ministry of Social Protection, Labour, and Employment of the Republic of Mordovia and its subordinate institutions, the All-Russian Public Organization of Veterans "Battle Brotherhood", the Council of Mordovian Regional Branch of the All-Russian Public Organization of Veterans (Pensioners) of War and Labour of Armed Forces and Law Enforcement Agencies, and the Ministry of Health of the Republic of Mordovia and its subordinate institutions ( $\mathrm{n}=$ 95). The type of sampling was targeted.

\section{Results}

According to the answers of social work specialists, war veterans apply to the Saransk Complex Centre of Social Services mainly for material and in-kind assistance (89.0\%). Such response options as socio-psychological, socio-legal, and socio-medical assistance and assistance in recreation and leisure activities were mentioned much less frequently. At the same time, as noted by the war veterans, they most often sought support either from the Saransk Complex Centre of Social Services or from social protection agencies (48\% and 34\%, respectively). 
However, as the survey showed, the main problems that concern the elderly, including veterans, were health problems (64\%), loneliness (56\%), conflicts with relatives (30\%), and financial problems $(60 \%)$ (the respondents could choose more than one answer). Thus, the state of health and the nature of social relations are the most important components of social well-being and act as dominant factors of the level and quality of life, along with material security.

The employees also indicated that the specialists of the Saransk Complex Centre of Social Services can most often help veterans with material problems (50.0\%), as well as leisure activities (20.0\%). In solving housing, household, socio-pedagogical, and socio-psychological problems (20.0\%), they more often stepped in as mediators. At the same time, the social activity and leisure activities of older people were at a fairly high level and were characterized by diversity. Thus, older people watched TV programs and movies, read fiction, played board games and crossword puzzles, and so on. However, some older people did not engage in any type of work activity (48.3\%) and lacked social (25.1\%) and leisure activities (5.6\%). Therefore, this group of older people had low social well-being, which had a negative impact on their livelihood and social health.

However, the process of ageing changes a person's social position, lifestyle, well-being, and social health. $56 \%$ of elderly veterans considered themselves lonely. This can be explained by the fact that it is difficult for them to adapt to the changing conditions.

The distribution of veterans' opinions regarding the indicators that primarily determine their social status and standard of living is of particular interest. Among the five most relevant indicators, the veteran respondents chose the following options: 1st place - the absence of war, peaceful sky, socio-economic conditions of living in society; 2nd place - the state of health; 3rd place - personal merits in society, positive evaluation of the veteran's deeds by society; 4th place - the level of social protection and security; $5^{\text {th }}$ place - the social status of relatives, family relations, and social activity.

Thus, a model of social protection for veterans to improve their social well-being and health should consider several levels: status, behavioral, resource, value, identity, and spiritual levels. Each of the highlighted levels contains objective and subjective factors influencing and determining social well-being. The proposed social model helps to explore and propose interventions (social support measures, assistance) to harmonize relations between veterans and society and ensure high social security and satisfactory social well-being.

1. The status level contains factors that determine the position of the veteran in society (development of social legislation, social policy model, and traditions). 
Elena G. Pankova, Dinara A. Bistyaykina, Tatiana V. Solovieva, Alena A. Antipova y Olga M. Lizina

Model of social protection for war veterans to improve their social well-being and health in the Russian Federation

2. The behavioral level touches upon the layer of relations and interactions of veterans in society (activity and passivity of veterans, their involvement in social, administrative, and public activities, reactions and actions of the state and society in relation to veterans).

3. The resource level relates to the skills, abilities, strategies, and resources that guide veterans' behaviour to maintain their social well-being and health (psychological, social factors, health status, infrastructure, etc.).

4. The value level determines the beliefs and values of veterans' contributions and perceptions of a decent life (value of veterans' contribution to society, value of health, and orientation towards a healthy lifestyle) as essential circumstances.

5. The identity level examines identity issues in the context of the adequacy of the veteran's perception of their social/material position in society and expectations and life goals (application of categorization to veterans).

6. The spiritual level contains an assessment of attitudes towards the contribution to the development of the society of veterans, the preservation of remembrance, and patriotism as indicators of the level of development of society and its moral "health" (the depth of understanding of social problems and solidarity).

Reforming the system of social protection of veterans to improve their social well-being and health should take place on three levels.

On the macrolevel, changes are required to form a legislative framework, overcoming the existing legislative gaps, which would ensure a high level of social protection for all categories of veterans.

Measures on the microlevel imply solving problems and developing a social protection system for veterans to improve their social well-being and health within municipalities, social protection institutions, and enterprises and deal with enhancing the role of veterans' public organizations.

Conducting work on the microlevel involves resolving or alleviating personal, subjective problems that impede the normal social functioning of veterans. The process of assistance on the microlevel involves both individual counselling and the organization of group work to improve the social well-being and health of veterans.

\section{Discussions}

Social well-being is directly proportional to the degree of success in solving important social problems and meeting the needs relevant to a 
particular category of people. Social well-being is related to the quality of life, the main characteristics of which are material security, health, education and employment, and social status. At the present stage in Russia, the system of social protection for veterans includes:

1. Pension support and measures to improve income levels of veterans: pension provision for veterans, general measures to support income levels of the older generation in the Russian Federation (e.g., social supplement to pensions, indexation of pensions), additional regional measures of social support and assistance to veterans.

2. Improvement of veterans' housing conditions and provision of social support measures for payment of housing and utility services: provision of housing for veterans, capital and current repairs of housing, social support measures for payment of housing and utility services, measures to create a comfortable social environment and infrastructure.

3. Medical care and rehabilitation, provision of medicines and technical means of rehabilitation, sanatorium and spa treatment for veterans, implementation of regional programs, including measures to increase active longevity and healthy life expectancy, development of geriatric care.

4. Tax exemptions concerning income tax, transport tax, property tax, land tax, and state duty.

5. Social services for veterans: individualization and targeting of social services for veterans in the Russian regions, development of medical and social services, hospital-substituting social service technologies, expansion of mobile (interdepartmental) teams to provide various services, and introduction of a long-term care system.

6. Promotion of employment and professional retraining of veterans: vocational training for those of pre-retirement age and implementation of additional employment services.

7. Raising awareness of veterans (including concerning their social rights).

8. Supporting the participation of veterans in social work and upbringing of children and the youth: state support for public associations of veterans, development of the social partnership, education, and patriotic upbringing.

The current system of social protection for veterans in the Russian Federation is multisubject. All subjects can be divided into federal, regional, and local, including the "third sector" (state bodies, social protection institutions, public organizations, etc.) (Bistyakina et al., 2019; Solovyova 
Elena G. Pankova, Dinara A. Bistyaykina, Tatiana V. Solovieva, Alena A. Antipova y Olga M. Lizina

Model of social protection for war veterans to improve their social well-being and health in the Russian Federation

et al., 2019). At the same time, the system of social protection of veterans remains open, i.e., in the process of functioning, it is constantly replenished with new elements and subjects.

The institutional mechanisms for the implementation of social protection of veterans include federal targeted (state) programs, which represent a special organized activity of state authorities to implement social support measures for this category of citizens based on targeted budget financing and attraction of other sources. Federal targeted (state) programs include legal, financial, economic, information, analytical, institutional, and organizational components. Particular attention for the establishment and development of the elements of social protection of veterans to improve their social well-being and health is paid in the framework of the federal project "The Older Generation", which provides for measures aimed at ensuring an increase in healthy life expectancy, the proportion of elderly and disabled citizens living in new-type residential social service organizations, the development of medico-social services for veterans, etc.

According to the experts, the development of the social protection system for veterans to improve their social well-being and health should be linked to the solution of the following urgent tasks.

1. The issues of rehabilitation of military personnel with disabilities need to be elaborated and detailed. The social and rehabilitation infrastructure for disabled combatants, especially in rural areas, needs to be developed at the level of municipalities, and there is a need for comprehensive rehabilitation centers for disabled combatants.

2. It is advisable to develop a coherent state (or regional) concept of social protection for veterans and disabled combatants, as well as their family members, with the formation of an appropriate legislative framework for this (through the introduction of amendments and additions to normative and legal acts).

3. The issues of education, vocational training, and employment of persons with disabilities and veterans of combat operations, guaranteeing their social integration and a decent standard of living, are topical.

4. It is advisable to create in the regions a system of social order, social grant, which will significantly facilitate and make more effective the work to solve the numerous social problems of the elderly and veterans, including such acute problems as health, leisure, employment, care for the elderly, etc.

5. It is necessary to share the successful experience of the regions in improving the social well-being and health of veterans and create and implement relevant Internet portals and services that allow for close inter-regional cooperation. 
6. Provision of information support to social service institutions and non-profit non-governmental organizations working with elderly people and veterans through the creation and maintenance of internet websites, production of regional newspapers or magazines free of charge for social protection institutions, and resumption of the practice of regular publication of information collections containing the generalized experience of social protection institutions.

7. Expansion of social guarantees and improvement of the welfare of combat veterans and members of their families.

8. Active engagement of veterans and disabled war veterans in local issues - reception of population, work with the youth, administrative, social, and legal, and information and reference work in municipal administrations, bodies/institutions of executive power, public organizations, etc.

9. There is a need to strengthen patriotic social work; it is advisable to create projects aimed at the patriotic education of the Russian youth using examples from the lives of combat veterans.

10. The work with elderly veterans should be as targeted and personalized as possible, with a focus on supporting family ties.

\section{Conclusion}

The modern system of social protection of veterans should aim to achieve the favorable social well-being of veterans.

Social protection of war veterans is multisubject; it includes diverse sociopolitical, socio-legal, socio-economic, socio-medical, socio-psychological, and organizational measures.

The practice of social protection of war veterans as a model of social protection continues to be transformed by demographic, social, legal, economic, and cultural factors. In response to today's social needs, the system of social protection should be more targeted, individualized, oriented towards a high quality of life for people who have rendered special services to the homeland; technologies allowing the normalization of the social and psychological well-being of this category of persons should be widely introduced into social practice.

Reforming the system of social protection of veterans to improve their social well-being and health should consider several levels: status, behavioral, resource, value, identity, and spiritual. Each of the distinguished levels contains objective and subjective factors influencing and determining social well-being; in turn, measures should address all three levels: strategic 
Elena G. Pankova, Dinara A. Bistyaykina, Tatiana V. Solovieva, Alena A. Antipova y Olga M. Lizina

Model of social protection for war veterans to improve their social well-being and health in the Russian Federation

level - the level of social policy (macrolevel); the level of organizations and social services (microlevel); individual level (microlevel).

\section{Acknowledgements}

The study was financially supported by the Russian Foundation for Basic Research and the Government of the Republic of Mordovia as part of the research project № 18-411-130001 \18.

\section{Bibliographic References}

BEN-SHALOM, Yonatan; TENNANT, Jennifer; STAPLETON, David .2016. "Trends in disability and program participation among U.S. veterans" In: Disability and Health Journal. Vol. 9, No. 3, pp. 449-456.

BISTYAKINA, Dinara Asymovna; SOLOVYOVA, Tatiana Vladimirovna; PANKOVA, Elena Gennadyevna. 2019. "Social support for veterans in the regions of the Volga Federal district" In: Humanities, socio-economic and social Sciences. Vol. 3, pp. 49-54.

BOLOTOVA, Viktorya Vladimirovna. 2016. "State social support of veterans of the great Patriotic war" In: Young scientist. Vol. 10, No. 114, pp. 960-962.

BURNELL, Karen; NEEDS, Adrian; GORDON, Kim. 2017. "Exploring the suitability and acceptability of peer support for older veterans" In: Quality in Ageing and Older Adults. Vol. 18, No. 2, pp. 120-130.

CHEN, Jason I; HOOKER, Elizabeth R; NIEDERHAUSEN, Meike; DOBSCHA, Steven K; TEO, Alan R. 2020. "Social connectedness, depression symptoms, and health service utilization: a longitudinal study of Veterans Health Administration patients" In: Social Psychiatry and Psychiatric Epidemiology. Vol. 55, No. 5, pp. 589-597.

DREBING, Charles; REILLY, Erin; HENZE, Kevin; KELLY, Megan; RUSSO, Anthony; SMOLINSKY, John; GORMAN, Jay; PENK, Walter E. 2018. "Using peer support groups to enhance community integration of veterans in transition” In: Psychological Services. Vol. 15, No. 2, pp. 135145 .

DUSHATSKY, L.E. 2004. Material and power resources of Russians in selfassessmentand socialwell-being. Sociological research,4,64-70.Available online. In: https://www.researchgate.net/publication/292272106 Material_and_power_resources_of_Russians_in_their_selfassessments_and_in_social_moods. Consultation date: 17/03/2020. 
FEDERAL LAW OF THE RUSSIAN FEDERATION NO. 5-FZ. 1995. "On Veterans". Available online. In: http://www.consultant.ru/document/ cons_doc_LAW_5490/.Consultation date: 17/03/2020.

GOOGE, Olga Anatolyevna. 2020. "Social protection of veterans of the fighting in the Altai region" In: Altai Bulletin of public and municipal services. Vol. 18, No. 18, pp. 14-16.

KOBOZEVA, Natalia Nikolaevna. 2007. "Social well-being as a sociological category” In: Bulletin of Stavropol state University. Vol. 50, pp. 117-122.

KRUPETS, Yana. 2003. Social well-being as an integral indicator of adaptation. Social research, 4, 143-144.

LONDADZHIM, Thierry. 2011. Social well-being of foreign students studying in Russian universities (Gender aspect). Women in Russian society, 4, 70-74. Available online. In: https://womaninrussiansociety.ru/ article/londadzhim-t-socialnoe-samochuvstvie-inostrannyx-studentovobuchayushhixsya-v-rossijskix-vuzax-gendernyj-aspekt-str-70-74/ . Consultation date: 17/03/2020.

OBRADOVIC, Nikolina. 2017. "War Veteran's Policy in Bosnia and Herzegovina" In: Revija za socialnupolitiku. Vol. 24, No. 1, pp. 93-106.

O’REILLY, Lisa; DOLAN, Pat. 2017. "The Role of Social Work Education and Training in Supporting Practitioners to Communicate with Children in an Age-Appropriate Manner" In: British Journal of Social Work. Vol. 47, No. 8, pp. 2438-2455.

PERKINS, Daniel F; ARONSON, Keith R; MORGAN, Nicole R; BLESER, Julia A; VOGT, Dawne; COPELAND, Laurel A; FINLEY, Erin P; GILMAN, Cynthia. 2020. "Veterans' Use of Programs and Services as They Transition to Civilian Life: Baseline Assessment for the Veteran Metrics Initiative" In: Journal of Social Service Research, Vol. 46, No. 2, pp. 241255 .

SOLOVYOVA, Tatiana Vladimirovna; BISTYAKINA, Dinara Asymovna; PANKOVA, Elena Gennadyevna. 2019. "Analysis of the activities of subjects of social protection of veterans to improve their social wellbeing in Russia and the Republic of MordoviaÖ" In: Kazan social and humanitarian Bulletin. Vol. 1, No. 36, pp. 47-52.

SWED, Ori; SHEEHAN, Connor McDevitt; BUTLER, John Sibley. 2020. “The Digital Divide and Veterans' Health: Differences in Self-Reported Health by Internet Usage" In: Armed Forces \& Society. Vol. 46, No. 2, pp. 238258. 
Elena G. Pankova, Dinara A. Bistyaykina, Tatiana V. Solovieva, Alena A. Antipova y Olga M. Lizina

UTSUMIEVA, Kamila Yunusova. 2015. "Sociological analysis of the quality of state budget services and their impact on the social well-being of the population" In: Bulletin of the North Caucasus Federal University. Vo. 1, No. 46.

XAVIER, Flavio; FERRAZ, Marcos .2003. “Elderly people's definition of quality of life” In: Rev Bras Psiquiatr. Vol. 25, No. 1, pp. 31-39. 
ISSN 0798-1406 Depósito legal pp 198502ZU132

\section{Cuestiones Políticas}

\section{Planilla de suscripción}

Nombre

Institución

Dirección

Ciudad País

Cheque de gerencia a nombre de: Universidad del Zulia (LUZ),

Facultad de Ciencias Jurídicas y Políticas, Ingresos Propios

Banco Occidental de Descuento, Cuenta corriente № 212700890-9

Tarifa de suscripción por un año (dos números):

Venezuela: Bs. 80 + Envío

Ejemplar solo: Bs. $40+$ Envío

América Latina \$ $40+$ Envío

Resto del mundo $\$ 50+$ Envío

Esta planilla debe ser enviada a la siguiente dirección:

Revista "Cuestiones Políticas"

Facultad de Ciencias Jurídicas y Políticas

Instituto de Estudios Políticos y Derecho Público

Apartado Postal 526, Maracaibo Venezuela

Puede adelantar información por: cuestionespoliticas@gmail.com

loichirinosportillo@gmail.com 